\title{
The Mobilization of Using Cultures and Local Government's Political-Economy Goals in Post-Reformation Banyuwangi
}

\author{
Ikwan Setiawan, Albert Tallapessy, Andang Subaharianto \\ Universitas Jember \\ Email: senandungtimur@gmail.com
}

\begin{abstract}
This article deals with an ethnic identity-based-power through the mobilization of Using cultures in Banyuwangi under local government policies in post-Reformation. By juxtaposing Foucauldian discourse, Gramscian hegemony, and political economy perspective, we discuss some cultural projects conducted by two Banyuwangi regents in post-Reformation periods, Samsul Hadi (2000-2005) and Abdullah Azwar Anas (2010-2015 and re-elected for 2016-2021 period). With different emphasized aspects, both of them created programs, which incorporated and mobilized Using cultures for accomplishing their political economy goals. Samsul legalized Using cultural expression, such as a local dance and language, as the way to strengthen the dominant-ethnic identity and reach consensus for his political authority. In more sparkling activities, Anas has transformed Using identity into various carnival programs, which, in one side, have supported tourism industry and, in other side, have helped him in gaining consensus for his hegemonic position. However, in the context of real cultural empowerment, those programs have not given positive effect for the cultural worker in the grass root.
\end{abstract}

Keywords: cultural mobilization, cultural policies, identity, political economy, Using

\section{INTRODUCTION}

One effect of 1998 Indonesian Reformation has been the emergence of indigenous communities' movements for re-claiming their economic, political, and cultural rights that had been repressed in the New Order period. However, some literatures criticize some reductive meanings of these movements, because, instead of empowering indigenous rights, many local elites - commonly rich individual, political figures and the descendants of ancient leaders - in some regions have mobilized ethnic issues and use them for reaching economic and political goals (Davidson, Henley \& Moniaga ed, 2010; Nordholt \& van Klinken ed, 2009). In governmental context, regional state regimes also have taken opportunities of this cultural euphoria by doing incorporation and commodification of dominant-ethnic-cultures in their regions as the ways to secure and attain their political-economic targets.

In this article, we will explain some efforts of the regional government of Banyuwangi in postReformation in mobilizing Using cultures without leaving their historical roots in the New Order periods. We will focus on some cultural projects conducted by two Banyuwangi regents, Samsul Hadi (2000-2005) and Abdullah Azwar Anas (2010-2015 and re-elected for 2016-2021). With different emphasized aspects, both of them created programs, which incorporated and mobilized Using cultures for accomplishing their political economy goals. Samsul legalized Using cultural 
expression, such as a local dance and language, as the way to strengthen the dominant-ethnic identity and reach consensus for his political authority. In more sparkling activities, Anas has transformed Using identity into various carnival programs that, in one side, have supported tourism industry and, in other side, have helped him in gaining consensus for his hegemonic position. Based on the brief explanation, we argue that cultural projects which give priority for a particular ethnic identity may become a strategic effort for Banyuwangi regents in reaching consensual agreements from the majority of local artists, indigenous leaders, cultural experts, and common people because they have had similar idealization for empowering Using cultures.

For getting more critical and comprehensive analysis, we juxtapose three perspectives, namely Foucauldian discourse, Gramscian hegemony, and political economy. Here is the logic of applying the three perspectives. We consider cultural projects issued by the two regents as discursive formation producing knowledge of Using as the dominant cultures. For Foucault (2002: 177), discourse is a group of statements related to singular formula of meaningful object and a limited group of statements related to similar discursive formation, although they do not form a unity of rhetoric. As regime of truth, discourse will emerge knowledge and construct various discursive subjects that also produce power operation and relation in particular historical settings (Hall, 1997: 49). It is important to note, discourse is not simply that translates struggles or systems of domination, but it is the thing for which and by which there is struggle; it is the power, which is to be seized (Foucault, 1981: 53). Further, the power operation is circulating; not top-down, not repressive, and coming from unlimited points (Foucault, 1998: 94-95). Following Foucauldian perspective, the cultural mobilization is a kind of discursive formation that creates various discourses about dominant-ethnic-cultures-from linguistic, arts, rituals, until traditional wisdoms - talked by the state apparatuses, cultural experts, artists, and ordinary people.

At that point, we see the significance of political economy perspective because the regimes have brought political-ideological motives in the mobilization. Political economy is a perspective criticizes economic and production base-structure that determine superstructure as ideology, religion, culture, morality, and socio-political process (Marx, 1991, 1992; Lebowitz, 2002; Wood, 2003). The capitalist ruling class with its financial capacity and production tools can drive mode of production that produces massive materials with commercial values. The ruling class can mobilize and monopolize particular ideologicalcultural knowledge in the structure of cultural products that will determine the cultural process in society (Granham, 2006; Maxwell, 2001; Adorno, 1991; 1997; Witkin, 2003; Leslie, 2005; Louw, 2001). The consumption process of the material in the society will lead to the change of cultural orientation - i.e. from subsistent to capitalist lifethat causes the change of socio-cultural practices. In the context of this article, we modify the ruling class not as capitalist class, but as the regional state regimes who also have had political-economic desire by creating the cultural projects.

The final goal of the cultural projects for the regime is to reach hegemony. According to Gramsci, hegemony is a mode of power that emphasizes intellectual, cultural, and moral leadership in which the ruling class articulates the necessity of the people, economically and ideologically, to create popular consensus and historical bloc that support the regime's authority (Gramsci, 1981; Howson \& Smith, 2008). One of the strategies to reach consensus is incorporating residual-traditional-and emergent cultural expressions in which the regime articulates them into official policies and products to convince the people agreement (Williams, 2006). However, hegemonic power is never stable and always needs newer negotiation-articulation because in its operation there can be resistance from the people such as local actors when they got the lack of advantages from the regime, economically and culturally.

The juxtaposition of the three perspectives in our study is not only significant for the analyzing process, but also for collecting data process by Using in-depth interview and participatory observation. From interviews with our informants, we collected data about the regime's cultural projects from the New Order era to the Reformation era that mobilize Using cultures, political condition 
in each period, and the responses of local actors toward the projects. From our observations, we collected data about forms of Using cultures that were mobilized in the cultural projects and their political economy consideration. In data analysis, we will apply the three perspectives systematically in order to interconnect the relations among data. Firstly, we will analyze Using cultures as dominant discourses in Banyuwangi context and the regimes' attempts to make them as essential knowledge, when the society has experienced cultural hybridity as the consequence of modernity. This essential knowledge has been acceptable for Using communities, because it has been appropriate with their necessity to develop cultural identity. Secondly, we will read critically the regimes' cultural projects - its forms, differences, and similarities - and discursive-practical effects toward socio-cultural configuration in Banyuwangi and its relation to tourism. Finally, we will criticize the political goal for hegemony through dominant-ethnic-cultures mobilization in the cultural projects, particularly its effects for local actors in Banyuwangi.

\section{A LEGACY OF THE NEW ORDER REGIME}

Culture is values, discourses, practices, and orientation that is moving dynamic, crossingover traditional and modern influences, and determining by socio-historical factors such as political economy system and social interaction in particular periods (Skelton \& Allen, 1999: 4-5). Culture, then, is something changing and transforming that is caused by various factors come from historical process-i.e. colonialism and capitalism - in which cultural members find themselves as subjects with multiple influences, motives, and orientations. With the same account, we see local culture as a complicated process of becoming from which its members experience contesting discourses and practices caused by the preservation of romantic views that assumed it as sublime-traditional values and the coming of newer or modern cultural elements in their daily activities. In local culture, actually, there have been a transformation or a change caused by the discursive influences of modernity. The long encounters with modernity in colonial period have taught local people how make suitable strategy to survive in the in-between space or the third space from where they have mimicked modern cultural elements as the dominant, but not quite the same, without have left their ancestors customs completely - hybridity (Bhabha, 1994: 114). However, as the consequence of long institutionalization of traditional wisdoms into their daily and ritual activities, local people have negotiated their knowledge into the dominant practices of modernity deferred its liberal knowledge.

Although in their cultural subjectivity local people have been being hybrid, they will recall communal solidarity and mobilize ethnic essential identity when there is foreign power that tries to dominate them. The mobilization of essential cultural identity is one characteristic of identity politics movement that emphasizes the significance of the mobilization of particular cultural symbols, values, and practices for accomplishing ideal goals by contesting the power that dominates a community or society (D'Cruz, 2008; Alcoff \& Mohanty, 2006). In the context of Using communities under the Dutch authority, for example, the people attempted to construct essential cultural subjectivity when migrantethnics, particularly Javanese and Madurese, came to Banyuwangi - as colonial soldiers, farmers, and plantation labors. The term Using was a stereotype name given by other ethnics and the Dutch apparatuses for Othering the natives with negative cultures such as fond of extravagant parties, permissive in sexual relation, and practicing witchcraft (Subaharianto, 1996; Sutarto, 2003, 2006; Sodaqoh, 1996). They 'took over' such constructed identity as survival energy in both to develop socio-cultural solidarity and to strengthen the concept "us" (Using people) and "them" (non-Using migrants). Using cultures with their attractive performance arts, then, have become more dominant in Banyuwangi since the New Order regime made some cultural projects based on essential paradigm with political economy goals.

In the New Order periods, the regional government was a subordinate subject of the national cultural policy of the central government. The policy promoted "the top-essences of regional cultures" and "Pancasila-based-cultures" as the key elements of national culture. The main purpose of this national culture was to prevent the return of 
feudal values and the negative effects of foreign values in the midst of development programs. Actually, the policy of national culture had multilevel ambivalence. In one side, the state idealized sublime national values and regional cultural expressions that would be appropriate for filtering the negative effects of foreign cultures. In other side, they restricted regional cultural forms that were assumed containing feudal values. However, for the sake of national development acceleration, the state regime encouraged Indonesian modernity that was absorbed from foreign positive valuesmodern sciences, technologies, and international investments. In other words, instead of empowering regional cultures, the policy tended to position local expressions as "celebration of cultural signifiers without the deep meaning or with controlled meaning based on the regime's interest". In addition, the national culture policy had its own goal to neutralize the residual collective memory of Sukarno leadership in the previous periods and to reach common consensus under the newer leadership of Suharto. By mobilizing and celebrating local cultural attractions, the state regime wanted the people forgetting the oppressive reality of their militaristic apparatuses and economic exploitation, so the regime would get hegemonic position (Setiawan \& Sutarto, 2014).

In the context of the New Order, the empowerment of Using identity in Banyuwangi originated from the ambition of Regent Djoko Supa'at to re-awaken cultural life after the 1965 bloody tragedy. Through discursive formation and praxis, the regional state regime articulated collective desires of cultural leaders, cultural experts, and local artists to produce Using expressions as Banyuwangi identity. The regional government gave the local actors opportunities for re-awakening traditional arts - gandrung (musicaldance), janger (traditional drama), and folksongsand campaigning Using language in cultural sphere of plural ethnic society. From the 1970s to 1980s, the Banyuwangi government carried out a routine cultural agenda, namely Using songs competition that originated from gandrung songs.

The government through regional state radio (RKPD/Radio Khusus Pemerintah Daerah, the Radio of Regional Government) also produced some popular Using programs. They asked some artists to produce radio drama in Using language and Using literature program. The two programs had a large number of audiences and made the programs the popular policies to socialize and to disseminate Using cultural identity continually in the plural society of Banyuwangi. The apparatuses of radio also sponsored a recording process of Using-lyric songs. Their musical instruments were the mixture of traditional musical instruments such as gamelan, angklung (bamboo musical instruments), kendang (a traditional percussion instrument made from the skin of cow), and the modern musical instruments such as guitar and violin, without commercial motive-merely for disseminating Using cultures as Banyuwangi cultural identity and the regime development programs as consensual discourses (Setiawan, 2010).

The essential cultural projects will discursively restrict other or emergent cultural creativity with different color, although it is still a part of the dominant ethnic culture. This Othering process is important for the regime because the different color will pollute the purity of the dominant identity and, of course, challenge the hegemonic power of the regime. Commonly, the regime never observes the content, discourses, and final goal of the different cultural expression-a judge from the cover syndrome. Probably, the different creativity is a part of discursive formation of the dominant culture and has a function to disseminate its knowledge into other ethnic groups, but with some modification in its aesthetic and physical forms. In the 1970s, for example, Fatrah Abal, a well-known song composer and electricity contractor in Banyuwangi, arranged Using songs with Malay instrument that was very popular at that time. For him, such cultural breakthrough had function to disseminate Using cultural expressions widely, beyond the negative assumption among Banyuwangi people and other ethnics such as Javanese and Madurese. The regime saw this creativity as disobedience toward the Using cultural standard. As the consequence, Fatrah got the penalty; the regime cancelled all his electricity contracts. However, he was consistent with his aesthetic choice and his Using songs with Malay instrument got popularity. What seems resisting 
on the surface will legitimate the regime to give economic and social sanctions to the different creative person. We call such phenomenon "a political-cultural schizophrenia" because the regime suspected the different cultural forms for having potency to mobilize discursive resistance among the people.

What important to criticize from such romantic idealization of local cultural mobilization - besides its political-ideological function-is its economic function. The state regime realized economic potency behind the uniqueness and exotics of local cultures in the label of tourism industries that got its popular momentum under the New Order regime. Instead of institutionalizing local cultures as hegemonic discourses to stabilize anti-colonial nationalism, the regime driven by their economic desires tried to circulate them in global tourism market. The government saw a great opportunity to sell out cultural attractions, artifacts, crafts, and rituals to satisfy the foreign tourists' gaze. Such economic motivation from essential cultural projects, actually, engendered a complicated problem, namely the return of stereotype representations that entangled the local people in traditionalism, while they lived under modern pathway.

In practical and discursive level, the incorporation of dominant local uniqueness in the cultural tourism project may result some different readings among local actors. In the 1990s, after having some preliminary researches in some Using villages, the regime decided to set Kemiren as "Desa Wisata Using" (the Using tourism village) and ordered the people to preserve their "rumah adat" (traditional house made from bamboo and wood) as traditional-unique cultural tangible attraction. Purwadi, one of cultural leaders in Kemiren, resisted against the policy because the restriction to build a brick house would oppress human rights and restrict their desire to experience modern architecture (Subaharianto \& Setiawan, 2012). His argument shows modern discourse in the mind of Using leader in Kemiren since the New Order periods until now, although most of the people have still believed and practiced traditional rituals. Under the massive development projects, from green revolution to media narratives, they have experienced many changes that made them not purely traditional in cultural taste, orientation, and practice. The desire to build brick houses as they have seen in television and city has been an example of modern thinking in village sphere. Such in-between playing that have challenged the state regime's exotic and essential paradigm shows that, since the New Order periods, the local people have had more adaptive strategy in facing socioeconomic change by practicing, at once, modern dominant elements and some of their ancestor traditions. We call this "intra-ethnic different reading" as deconstructive reaction towards the grand-narrative of the state projects that is assumed as regime of truth with their empirical discursive formation.

\section{POLITICIZING CULTURES AND CULTURALIZING POLITICS}

One of dominant trends in the regional level in post Reformation period has been the mobilization of "Putra Asli Daerah" issue [the region's native descendant] for taking political-administrative authority. At least, there are two major reasons for the issue. Firstly, the native can understand the regional potencies, society, and cultures for bringing better conditions. Secondly, the rising sentiment of local people toward the failure of the New Order regime in the previous periods to empower their life makes the discourse of region's native descendant reaches popularity in the local level. As one of political strategies, particular candidates of regent or governor often construct themselves to dominant-ethnic identity for gaining public sympathy and winning election. As the consequence, when they were elected as regional leaders, they will give more attention to dominantethnic community who gave political supports; a repetition of cultural politics as done by the New Order regime with newer meaning.

In Banyuwangi, Regent Samsul Hadi (20002005) repeated Using cultural mobilization with primordial tendency - Using as superior subject than other ethnics. Supported by cultural experts, he made two important cultural policies in his era, namely (1) gandrung as Banyuwangi welcoming dance through the Regent's Decree No. 1472003 (Basri, 2008) and (2) Using language as local curriculum in elementary and junior high school. Although its origin has become polemic until 
today, gandrung for majority of Using people has been acknowledged as the most wonderful dance heritage (Effendy, 2008). Its regional, national, and international popularity of gandrung made Samsul legalized it as both tourism mascot and cultural identity. The legalization was followed by (1) the making of giant gandrung dancer statue, (2) the training of professional gandrung dancer by Culture and Tourism Board, (3) the writing of gandrung by Blambangan Art Board, and (4) the promotion of gandrung to other cities, both in Indonesia and foreign countries, as Surabaya, Jakarta, Hong Kong, and some cities in USA. Moreover, gandrung-ization in the forms of pictures and statues became dominant color in villages and city landscape.

The gandrung project got positive response from Banyuwanginese cultural experts because they would have power to represent it in various discursive explanation-media narratives and academic reports. For gandrung artists, they would get legal support to continue their creativity and to gain economic beneficiary through performance. In this case, we see 'a meeting point' between the state regime's political-cultural desire and the local actors' economic-cultural necessity in the mobilization of local cultures. The state regime can take the more important role by incorporating residual-but-popular art from which they will get consensus from the local actors and people for establishing political power. Further, there is a modern-economic motivation behind such project, namely the promotion of cultural tourism agenda as strategic way to get financial advantage. This is a kind of hybrid-cultural-policy which the state regime a chance to support traditional art preservation and to get economic reward from the activity.

However, when the state cultural projects become hegemonic, there is always problem related to the persons or groups who have legal right to promote them and to modify or change their aesthetic structures. The government apparatuses wanted to perform gandrung with some new dance standards that were different to gandrung terob (performed in hajatan, a traditional party for celebrating a particular rite of lifecycle). The regime ordered gandrung artists who had legal sanggar (legalized art group) to perform gandrung with the new aesthetic structure, also without alcoholic drinks. This choice made gandrung artists with no sanggar marginalized in the euphoria of the regime projects. The sanggar artists enjoyed financial benefit through gandrung promotion in Indonesian big cities and international cities. In our view, such aesthetic standardization is "a cultural accident" caused by the projects of cultural revival that does not meet the necessity of local actors in lower level. This cultural accident shows that the incorporation of identity politics may cause conflict among local actors with the same cultural background.

Further, the policy of gandrung, up to now, has emerged oppositional response from Using people with Islamic background in some villages at Kabat and Songgon Sub-districts. They have neglected gandrung performance in their villages because this dance brings immoral elements as alcoholic drink, erotic body of the dancers, and the historical background of gandrung lanang, male dancer (Anoegrajekti, 2011: 93). In addition, the same ethnic members from other villages have had cultural jealousy when their communities have not gotten attention from the government. This cultural tension shows that in the level of intra-ethnic have existed a latent problem, particularly when (a) a group of people with strict religious perspective commits to Othering other group assumed as the profane one and (b) other communities in the same ethnic are not included in the cultural projects that make them cannot enjoy economic and cultural advantages.

Beside the policy of gandrung, Samsul also legalized Using language as one of local curriculum contents in all elementary and junior high schools in Banyuwangi. This legalization emerged inter-ethnic tension because non-Using people saw this local curriculum as an imperative strategy without understanding of multicultural reality in Banyuwangi. Pro factions saw the policy as political-cultural triumph because for long time under the New Order regime, Using students should learn Javanese language that was historically identified as oppressor element. It engendered both a tendency of Othering other ethnic groups, as Javanese and Madurese, and repressive language policy that made other ethnics must learn Using language. It was a transformation 
of Javanese language policy for Using students in the New Order era. However, local educated elites, as discursive subjects of "Using pride" did not understand such problem as the important one because they only wanted to celebrate the linguistic triumph as a significant-historical event for developing and strengthening Using identity (Sentot, 2008).

With the similar tone, the local artists who got advantages under his authority saw Samsul as the figure of political-cultural leader who really cared to their economic problems and had a good will to position them in honor position. His willingness to share money to the artists made them appreciating him as a subject of comparison when his successor has failed to develop and empower Using cultures. In addition, in structural positions, Samsul promoted the state apparatuses from Using ethnic to handle strategic bureaucratic positions. In this case, the collaborative incorporation of dominant-ethnic-cultures, education, and bureaucratic structures will persuade consensual agreement from the subordinate class and open the way for hegemonic power in regional level.

From the Using-ization projects in Banyuwangi under the authority of Samsul Hadi regime, at least, we see three problems in hegemonic power operation through dominant-ethnic-cultures mobilization. Firstly, the essentialist cultural projects will emerge politicizing cultures and culturalizing politic. While the first shows the regimes' mechanism to politicize particular cultural expression as the way to include the local actors in their power formation, the latter considers cultural primordial-ism to determine some political structures. Secondly, instead of its idealized function to resist foreign dominant power, the cultural mobilization will make power relation in political works appearing as something normal because the regime can articulate the populist desire to empower dominant-ethnic cultures. Thirdly, the possibility of intra conflicts among local actors and inter conflicts with other ethnic members that have lack of advantageculturally and economically-from the projects.

\section{COMMODIFYING ETHNIC CULTURES INTO GLOBAL TOURISM MARKET}

Under Regent Ratna Ani Lestari (the successor of Samsul Hadi, 2005-2010, hereafter RAL), the regime's cultural projects had different color. In the political process, Samsul's instruction to local actors and bureaucratic apparatuses to elect RAL — although she is not Using — was one of the important factors for her triumph in regent election. It means that Using ethnic through Samsul figure was still becoming significant factor in political election. Unfortunately, RAL did not create newer cultural programs that can empower Using cultures. Although she continued previous programs such as Festival Kuwung, a cultural carnival to celebrate Banyuwangi birthday, and the Training of Professional Gandrung, many local actors mocked her as "being too Balinese" because of her marital position as the wife of Regent Jembrana, Bali, and as "not knowing Using customs". Bad evaluations toward RAL leadership were a form of cultural disappointment framed by the past-ideal-romantic imagination under the New Order and Samsul regime. In other words, primordial views based on essential culture, in one side, may become a symbolic resistance toward political leadership with less attention to the dominant-ethnic culture and, in other side, may continue stigmatic tradition in viewing other ethnic groups.

Abdullah Azwar Anas (hereafter AAA), Banyuwangi regent for 2010-2015 - and re-elected for 2016-2021 period - has not wanted repeating RAL's faults in perceiving Using cultures. Driven by his economic and political desires, he has continued some previous programs and created newer cultural programs based on Using cultural richness. However, he, as a young leader, has had different perspective with the previous regents. With arguments to empower the life of traditional artist economically and the great cultural potencies of Banyuwangi, he has promoted some discourses on Using cultures that need to be managed with commercial tourism standards since his first period of leadership. It means a new globally oriented cultural project need to conduct. In the opening speech of Padang Ulan performance at the Hall of Tourism and Cultural Board, 22 July 2011, he confidently stated:

In the future, we will find a breakthrough to develop and preserve our cultures....I encourage the government apparatuses 
related to cultures and tourism to approach traditional arts with tourism perspective. It is important because we need to utilize traditional arts potency to empower tourism activities. We need to create international network to attract global tourists to come here, to view our cultural attractions. Therefore, at 22 October 2011, we will have Banyuwangi Ethno Carnival (BEC). I purposely invite manager of Jember Fashion Carnival (JFC) because now he has networks with 180 international photographers. Therefore, please, do not make useless debates about BEC. For the traditional artists, do not worry, we will not erase our traditional characters. BEC is important to promote our cultural heritage. Then, for the real tradition programs, we will hold Festival Kuwung to expose Banyuwangi traditions. Once again, we need to compact to develop Banyuwangi arts and cultures. We must show to the foreign tourists that we are society with great cultures.

By Using the subject, "we" in his speech, AAA brilliantly includes Banyuwangi people, especially local actors, as integral part of his futuristic project. To minimize the local actors' resistance towards the plan, AAA conceptualizes two oppositional paradigms under the discourse of arts and cultures empowerment. Firstly, he promotes indigenousromantic perspective which positions Banyuwangi arts and cultures as the form of local wisdoms that needs to preserve in contemporary life. Secondly, he issues tourism economy, which idealizes cultural attractions as integral part of tourism activities that can increase financial income. Such binary opposition implies the regime's desire to drive tourism economy based on the cultural attractions. To realize the ideal goal, AAA issues BEC proposal and invites JFC management as consultant in the carnival. AAA believes that the JFC's national and international publication will guarantee the promotion of BEC as global fashion carnival based on Using cultures.

As a strategy to construct BEC as the first great cultural project under AAA's regime, the official-steering team prepared enlarging public opinion of this program through media. Regional television station, JTV, for example, broadcasted live street fashion shows, which modified gandrung, janger, and kuntulan costumes in more colorful and wonderful mode. Radar Banyuwangi, a regional media (Jawa Pos Group), reported BEC as its headline. Of course, the official-steering team needed to allocate much money to contract the two media. Some national televisions also reported BEC in their news program. Some foreigner photographers took pictures from the fashion carnival. Indeed, the first BEC, 22 October 2011, was successful program because thousands people watched and some regional and national media reported it although to measure the tourism and economic beneficiary was not easy business.

Discursively, local actors in Banyuwangi were divided into two factions in responding BEC, accepting and resisting. For the resisting actors, BEC would marginalize and 'kill' Using arts because the project only "looks like Using" without touching the roots of empowerment problems and gave economic benefit for non-Banyuwangi creators. The accepting faction, particularly cultural experts and institutions who has had close relations with the regime, conceived $\mathrm{BEC}$ as a great formula to promote Using cultural richness globally. However, the regime as the leading class in political-cultural formation always had strategy to face discursive resistance of the subordinate class. The cultural bureaucratic apparatuses in Banyuwangi gave a chance to the resisting artists to participate in BEC by both following the official rules of JFC management and giving a little of traditional color - the parade of grandrung dancers and ethnic music collaboration. This strategy made them participate in BEC. When we asked one of them for this contradictory, he answered, "Well, my friends and I are only citizens. When our leader asked us to participate, it is impossible to neglect."

The success of BEC, Banyuwangi Beach Jazz Festival, and Parade Gandrung Sewu (A Parade of A Thousand Gandrung) in 2011 has made AAA and his apparatuses creating more various and sparkling programs under banner Banyuwangi Festival in the following years. However, the obligatory cultural-carnival menus in Banyuwangi Festival have been BEC, Banyuwangi Beach Jazz Festival, Parade Gandrung Sewu, and Banyuwangi Batik Festival. Interestingly, from 2012 to 2015, 
there had been multiplying number of the various events in Banyuwangi Festival: 7 events in 2012, 15 events in 2013, 23 events in 2014, 36 events in 2015, and 53 events in 2016. In 2017, Banyuwangi government will make 66 events.

Since 2011 until now, the combination of cultural carnivals, international sport activities, and wonderful natural landscape, have delivered some significant achievements in tourism development for Banyuwangi government under AAA. In 2012, for example, the government of Banyuwangi achieved "The Most Improved" award and in 2013 achieved "The Most Creative" award in Travel Club Tourism Award (Rachmawati, 2013). Of course, those achievements have become important signifier for the success of AAA as the visionary leader in the history of Banyuwangi. Furthermore, in a international event, the government of Banyuwangi in 2106 got "UNWTO Awards for Excellence and Innovation in Tourism" in The Innovation of Public Policy and Governance category. This achievement was not peculiar because since the first term of his authority, precisely in 2011, AAA has committed to the internationalization of Banyuwangi tourism destination to attract the coming of foreign tourists into this east frontier of Java through some spectacular events. Slamet Kariyono, the secretary of the regency, claimed that during the last five year (2010 to 2015), there was the radical leap of tourists visiting Banyuwangi (Rachmawati, 2016). Domestic tourists increased $161 \%$ from 651,500 people in 2010 to $1,701,230$ people in 2015 , while foreign tourists increased $210 \%$ from 13,200 people in 2010 to 41,000 people in 2015 .

AAA and his apparatuses, clearly, have transformed flexibly the exotic uniqueness of Using cultures into carnival modes which visually have attracted the viewers of Banyuwangi Festival. Although seems repeating the New Order policy of cultural tourism, AAA has had more brilliant perspective based on global tourism market. It is impossible to reach a great economic beneficiary through the cultural projects without promoting them globally. The problem is that the fashion carnival, actually, is not empowering Using local values, but merely re-packaging of surface-cultural signifiers for international taste. In other words, the regime does not think essentially any more, but transforms local cultures into a celebration of aesthetic signifiers to absorb post-modern taste that deconstructs binary opposition between the traditional and the modern. However, the axe of this program is market law. Local cultures in this consideration only become raw materials incorporated and represented by the regime through carnival cultural products that serve the global tourism market without empowering the locality itself.

Ironically, the government has not given any chance for folk artists and their art performances, such as angklung (musical instruments made from bamboo performed with a dynamic rhythm) and gandrung to show their aesthetic works through particular moments in Banyuwangi Festival. Indeed, there has been gandrung parade, but it has been difficult for empowering this folk art and its artists because the government has no planned programs that have touched their real problems. Taking folk arts merely as raw material to be commodified into palatial fashions does not mean making serious effort for evolving them and giving the artists sustainable cultural benefit. Instead, the governmental regime with neoliberal orientation intentionally makes various parades and festivals merely for valorizing artificial meaning of the local art performance and rituals. Of course, once again, political economic goals are the dominant motives behind ethnic identity celebration through commodification of Using cultures, particularly for negotiating hegemonic position. Therefore, talking Using cultures in Banyuwangi Festival will raise the greater problems for the local actors, particularly the regeneration of local performing arts, if the government apparatuses have no precise policy in empowering it.

AAA and his apparatuses have incorporated and commoditized Using cultures as raw materials for the carnival products. In this context, we can see Using identity is not only positioned as the cultural core which cannot be re-interpreted, but also as the flexible identity that can be "played" for supporting economic and political interest of the regional state regime. As a younger politician and leader with capable knowledge of business and politics, AAA has been aware about many wonderful aspects of Using cultures that may fulfill the desire of metropolitan people toward exotic, primitive, and 
ethnic values in the midst of their postmodernity. Banyuwangi Festival, for us, is an exemplar how the regional state regime mobilizing dominantethnic-cultures, not merely for empower them as local identity, but also to follow the global tourism market. In this perspective, the regime imagines to get great benefits, economically and politically. Financial income from cultural tourism activities today becomes a global trend in which ethnic uniqueness re-packaged in commercial products for serving foreigner tourists who still desire exotic cultures; ethnicity incorporation (Comaroff \& Comaroff, 2009). Politically, the regime, once again, will gain political consensus from the people and local actors - although not all-for promoting dominant-ethnic-cultures globally and developing them in contemporary period. In other words, the hybrid-cultural policy always brings the spirit of dominant-ethnic-culture into the newer modern understanding with economic and political orientation. In 2016 regional election, AAA was reelected to rule Banyuwangi until 2021. It proves that all his sparkling carnivals with wide media coverage regionally and nationally also have given positive impact for Banyuwangi people, so they elected AAA for the second period.

\section{CONCLUSION}

At these concluding remarks, we just want to re-articulate some critical conceptions about the capability of the regional state regimes in post-Reformation Banyuwangi for incorporating, articulating, and transforming Using cultural identity into their cultural projects. Samsul Hadi was the successful and prominent regent who could raise communal pride and solidarity among Using people. His paradigm in cultural projects, politicizing culture and culturalizing politics, generally could be accepted by the majority of cultural experts, artists, and common people because he and his apparatuses might provoke cultural sentiments of Using people who had been subordinate community under the New Order regimes. By giving priority to Using traditional arts and rituals in cultural programs and legalizing gandrung and Using language, Samsul actually had a great awareness about the potentiality of ethnic identity as the significant instrument in reaching all his economic and political ambitions.
AAA has brought the transformation paradigm in cultural projects by creating many wonderful carnivals because since the first term of his leadership, he has targeted selling exotic Using cultural richness into global tourism market. Therefore, he has set various programs by modifying many Using traditional arts and rites into the newer carnival expressions, such as in BEC, Banyuwangi Batik Festival, etc. For developing various tourism destinations and attractions, those cultural programs have been very interesting for local inhabitants, domestic tourists, and foreign tourists. Economically, the coming of them into Banyuwangi will increase the governmental income. Politically, although AAA is not Using descendant, because of his success in promoting Using cultures and other natural destinations into national and global tourism market, he has gotten political public consensus for his leadership.

From the two cases, we can see that in postReformation periods, the massive indigenous movements who mobilize dominant-ethnicculture for recalling communal solidarity can be entrapped into reductive meanings, especially when the regional state regimes incorporate the movements. The ideal intentions for empowering ethnic communities economically, politically, and culturally can be hijacked by the regional state regimes that have their own political economy goals. Indeed local actors who can lobby the governmental apparatuses will get economic advantages because they will get financial funding and involve in ceremonial cultural agendas. However, the majority of local artists who have no such capacity will get nothing from the identitybased-projects. In this context, instead of becoming the solidarity capital of indigenous movements, ethnic cultural mobilization can be "the celebration of traditional signifiers" that gives no maximum positive effect for the communities.

\section{REFERENCES}

Adorno, Theodor W. (1991). The Culture Industry: selected essays on mass culture. London: Routledge.

Alcoff, Linda Martín, and Satya P. Mohanty (2006). "Reconsidering Identity Politics: An Introduction". In Linda Martín Alcoff, Michael Hames-García, Satya P. Mohanty, \& Paula M. 
L. Moya (eds). Identity Politics Reconsidered. New York: Palgrave Macmillan.

Anoegrajekti, Novi (2011). Membaca Tanda-tanda: Estetika Sastra dan Budaya. Jember: Jember University Press.

Anas, Abdullah Azwar (2011). "Opening Speech in Padang Ulan Performance", 22nd July, the Hall of Tourism and Cultural Board, Banyuwangi.

Basri, Hasan (2008). "Kesepian di Tengah Keramaian”. Retrieved on 1st May 2015, from http:// www.desantara.org/05-2008/781/gandrungkesepian-di-tengah-keramaian/.

Bhabha, Hommi. K. (1994). The Location of Culture. London: Routledge.

Comaroff, John L. \& Jean Comaroff (2006). Ethnicity Inc. Chicago: The University of Chicago Press.

D’Cruz, Carolyn (2008). Identity Politics in Deconstruction: Calculating with the Incalculable. Hampshire: Ashgate Publishing Limited.

Davidson, Jamie S., David Hanley, \& Sandra Moniaga (ed) (2010). Adat dalam Politik Indonesia (Indonesian trans. E.O. Kleden \& Nina D). Jakarta: Yayasan Pustaka Obor Indonesia \& KITLV-Jakarta.

Effendy, Bisri (2008). "Membaca Pariwisata SeniBudaya: Tari Gandrung Banyuwangi". Retrieved on 3rd June 2015, from http:// puspek-averroes.org/2008/05/09/membacapariwisata-seni-budaya-tari-gandrungbanyuwangi/.

Foucault, Michel (2002). Arkeologi Pengetahuan. (Indonesian trans. H.M. Mochtar Zoerni). Yogyakarta: Qalam.

Foucault, Michel. (1998). The Will to Knowledge, The History of Sexualities Volume 1 (English trans. Robert Hurley). London: Penguin Books.

Foucault, Michel (1981). "The Order of Discourse", Inaugural Lecture at the College de France, $2^{\text {nd }}$ December 1976, re-published in Robert Young (ed). Untying the Text: A Post-Structuralist Reader. Boston: Routledge \& Kegan Paul Ltd.

Garnham, Nicholas (2006). "Contribution to a Political Economy of Mass-Communication". In Meenakshi Gigi Durham \& Douglas M. Kellner (eds). Media and Cultural Studies Keyworks. Victoria: Blackwell Publishing.

Hall, Stuart (1997). "The Work of Representation". In Stuart Hall (ed). Representation, Cultural
Representation and Signifying Practices. London: Sage Publication in association with The Open University.

Howson, Richard \& Kylie Smith (ed) (2008). Hegemony: Studies in Consensus and Coercion. London: Routledge.

Lebowitz, Michael (2002). "Karl Marx: The Needs of Capital vs. The Needs of Human Beings". In Douglas Dowd (ed). Understanding Capitalism: from Karl Marx to Amartya Sen. London: Pluto Press.

Leslie, Esther (2005). “Adorno, Benjamin, Brecht and Film". In Mike Wayne (ed). Understanding Film: Marxist Perspective. London: Pluto Press.

Louw, Eric. (2001). Media and Cultural Production. London: Sage Publications.

Marx, Karl (1991). The Capital: A Critique of Political Econnomy Volume 3 ((English trans. David Fernbach). London: Penguin Books in association with New Left Review.

(1992). The Capital: A Critique of Political Econnomy Volume 2 (English trans. David Fernbach). London: Penguin Books in association with New Left Review.

Maxwell, Richard (2001). "Why Culture Works". In Richard Maxwell (ed). Culture Works: The Political Economy of Culture. Minneapolis: University of Minnesota Press.

Nordholt, Henk Schulte \& Gerry van Klinken (ed) (2009). Politik Lokal di Indonesia (Indonesian trans. Bernard Hidayat). Jakarta: Yayasan Pustaka Obor Indonesia \& KITLV-Jakarta.

Rachmawati, Ira (2013). "Banyuwangi Raih Tourism Award 2013". Kompas.com. Retrieved on 15th August 2015, from http://travel.kompas.com/ $\mathrm{read} / 2013 / 12 / 22 / 0745289 /$ Banyuwangi.Raih. Tourism.Award.2013.

(2016). "Empat Strategi Banyuwangi Raih Penghargaan Pariwisata PBB”, Kompas.com. Retrieved on 22nd Januart 2016, http://travel. kompas.com/read/2016/01/22/104123127/ Empat. Strategi. Banyuwangi.Raih. Penghargaan.Pariwisata.PBB.

Sentot, Hasan. (2008). "Ada Apa dengan Wong Using”. Retrieved on 18th June 2015, from http:// hasansentot2008.blogdetik.com/2009/01/15/ ada-apa-dengan-wong-Using/.

Setiawan, Ikwan \& Sutarato (2014). "Transformation of Ludruk Performances: From Political 
Involvement and State Hegemony to Creative Survival Strategy". Jurnal Humaniora, Vol. 26, No. 2, 187-202.

Setiwan, Ikwan (2010). "Merah Berpendar di Brang Wetan: Tegangan Politik 65 dan Implikasinya terhadap Industri Musik Banyuwangen." Jurnal Imaji, Vol. 8, No. 1, 116-135.

Skelton, Tracey \& Tim Allen (1999). "Culture and global change: an introduction". In Tracey Skelton \& Tim Allen (eds). Culture and Global Change. London: Routledge.

Subaharianto, Andang (1996). Mitologi Buyut Cili Dalam Pandangan Orang Using di Desa Kemiren Kabupaten Banyuwangi. (Unpublished research report). Lembaga Penelitian Universitas Jember, Jember.

Sutarto, Ayu (2006). "Sekilas tentang Masyarakat Using”. An article presented at Acara Pembekalan Jelajah Budaya 2006, Balai Kajian Sejarah dan
Nilai Tradisional Yogyakarta, 7-10 Agustus. - (2003). Etnografi Masyarakat Using. (Unpublished research report). Dinas Pendidikan dan Kebudayaan Provinsi Jawa Timur, Surabaya.

Zainuddin, Sodaqoh, et al. (1996). Orientasi Nilai Budaya Using di Kabupaten Banyuwangi. (Unpublished research report) Lembaga Penelitian Universitas Jember, Jember.

Williams, Raymond (2006). "Base/Superstructure in Marxist Cultural Theory”. In Meenakshi Gigi \& Douglas M. Kellner. Media and Cultural Studies KeyWorks. Victoria: Blackwell Publishing.

Witkin, Robert W. (2003). Adorno and Popular Culture. London: Routledge.

Wood, Ellen Meiksins (2002). The Origin of Capitalism: A Longer View. London: Verso. 